\title{
Well, it is WELL: Language and Human Interest in a Virtual Community
}

\author{
Obododimma Oha \\ University of Ibadan \\ o.oha@mail.ui.edu.ng
}

\begin{abstract}
This paper discusses the pursuit of humanistic interests by Netizens, with particular reference to discourse in chat groups located in Whole Earth 'Lectronic Link (WELL), a virtual community founded by Stewart Brand and Larry Brilliant in 1985. It explores how language becomes a vital tool in building, reinventing, and promoting sense of community and creative freedom. It also examines the ways that conflicts are prevented and/or managed in the cyber conversations, and the struggles to live electronically with Netiquette. The quest to cater for human interests through the use of language in cyber conversations implies that there is a limit to freedom exercised by Netizens. Virtual communities like the WELL, configured as "a word palace", present useful data on patterns of behaviour that the New Information and Communication Technologies, especially the Internet, have generated, and which contemporary discourse scholarship cannot afford to overlook. A "word palace" poses a great challenge to human identity and mediations of such identities, relationships, and goals; it simulates and communicates power and power struggles, even when it appears to either minimize or transform such power to cooperation. Thus the WELL Netizen builds power through discourse and language that cater for "WELLbeing".
\end{abstract}

Sometimes the web can be an excellent research tool. For example, a few clicks into cyberspace and I am looking at an automated German-English Dictionary. So the first word I enter is SEIN. It comes back BE or BEING. Then I enter FELD and it comes back FIELD. That's it! I can't help but dance around my artist studio in ecstatic joy! Seinfeld is really not just "about nothing". Or is at least about more than nothing. It's all embedded in the secret code of Jerry's last name, the identity of his moniker cum gracerhood. He is the Being-Field or, I prefer, The Field of Being, one nuzzled inside the chaotic heartbeat of the pounding human condition (Mark Amerika, (n.d.) "My Oblivion", Blackice). 
The pursuit of freedom in cyberspace ${ }^{1}$, considered as a humanistic endeavour, affects language. In fact, such pursuit of freedom partly seems to be a linguistic enterprise. Language has, indeed, been one of the means through which the humanistic pursuit of freedom is enacted, and cyberspace provides a convenient context especially because it has been perceived as promoting freedom and its infringement. Language being a site for the enactment of humanistic pursuits in cyberspace should not be surprising for, as Richard Hooker (1996) has observed, it was in "the arts of language" (grammar, dialectic, and rhetoric) that "the [classical] humanists centered their attention". The classical humanistic interest in the "arts of language" has not waned, considering the rigorous theorizing and analysis of the principles of humanism in language teaching, which one finds in the writings of scholars like Earl W. Stevick (1990), Gertrude Moskowitz (1978), C.A. Curran (1976, 1978), Caleb Gattegno (1987, 1988), and G. Lozanov (1979). ${ }^{2}$ Humanistic language teaching emphasizes human feelings, social relations, responsibility, intellect, and selfactualization, as Stevick (1990: 23-24) has explained. Under feelings, human emotions and aesthetic appreciation are considered important, and so efforts are made "to reject whatever makes people feel bad, or whatever destroys or forbids esthetic enjoyment". The social relations component involves encouraging friendship and cooperation, while responsibility involves an acceptance of "the need for public scrutiny, criticism, and correction". The free exercise of the mind, intellectual freedom to pursue reason, knowledge, and understanding, is encouraged under intellect. Self-actualization focuses on the realization of full human potentials, of one's talents, and so discourages conformity because it cripples independent creative thinking.

What humanists generally emphasize is human interest in all things. Thus humanism could simply be explained as a strong commitment to human interest, and a strong opposition to conventions or systems of thinking that make such interest secondary or subordinate to some other interests. Defined this way, humanism sounds redemptive and totally rational. I will not concern myself with all the debates about the claims made by humanists. But it is important to note that humanists have not been friendly with institutional control which inhibits individual freedom.

The emergence of the Internet or the Web has meant a facilitation and future for humanism, especially because it has created a space (the cyberspace) which is not really a place, the inhabitants of which has been identified as "Netizens". In the real world, the subjects are citizens, whose human interests are constantly monitored and censored by the Symbolic Order. Netizens could be viewed as "citizens of the Net", as Hauben and Hauben (1997) alternatively refer to them, though not everyone who communicates with or in the Net. To this end, Michael Hauben (1995 [1997:x]) argues as follows:

Netizens are not just anyone who comes online. Netizens are especially not people who come online for individual gain or profit. They are not people who come to the Net thinking it is a service. Rather, they are the people who understand it takes effort and action on each and everyone's part to make the Net a regenerative and vibrant community and resource. Netizens are people who decide to devote time and effort into making the Net, this new part of our world, a better place. Lurkers are not Netizens, and vanity home pages are not the work of Netizens. 
In this paper, I am interested in Netizenship that is characterized by humanistic linguistic pursuits. Given that the Net itself makes humanism achievable, Netizens are the vanguards of the new Net Humanism. As a matter of fact, interactive life in Netizenship is associable with the five areas emphasized by Humanism, which were explained earlier in this paper, but perhaps one that appears to be prominent is social relations. Netizens want to cooperate and assist one another; it is discourse that brings their world - the cyberspace - into being. It is a world in which contact through discourse abolishes distance - the physical, as Cairncross (2001) has explained, the social, and the psychological. Netizens want the world to shrink, to really become a community. The term "Virtual Community" has therefore been used to describe "social aggregation[s] that emerge[s] from the Net when enough people carry on those public discussions long enough, with sufficient human feeling, to form webs of personal relationships in cyberspace". (Rheingold, 1993; http://www.rheingold.com/vc/book/intro.html; Emphasis mine). The humanistic concerns in Netizenship communication have been identified by Hauben and Hauben (1997:4): "Netizens make it a point to be helpful and friendly - if they feel it will be worthwhile. Many Netizens feel they have an obligation to be helpful, answer queries, and follow up on discussions; to put their opinions into the pot of opinions". Howard Rheingold in his The Virtual Community: Homesteading on the Electronic Frontier (1993, online) has clearly outlined the various ways that the virtual community is discursively organized:

People in virtual communities use words on screens to exchange pleasantries and argue, engage in intellectual discourse, conduct commerce, exchange knowledge, share emotional support, make plans, brainstorm, gossip, feud, fall in love, find friends and lose them, play games, flirt, create a little high art and a lot if idle talk. People in virtual communities do just about everything people do in real life, but we leave our bodies behind. You can't kiss anybody and nobody can punch you in the nose, but a lot can happen within those boundaries.

Rheingold provides instances from his personal experiences with Whole Earth 'Lectronic Link (WELL), a virtual community founded by Stewart Brand and Larry Brilliant in 1985, which he joined the same year. WELL (playfully configured in the book by Rheingold as a well that one can draw water from as well as fall into) is "a computer conferencing system that enables people around the world to carry on public conversations and exchange private electronic mail (e-mail)". Through WELL, things get done, even faster and more efficiently than "in real life" (IRL), as Rheingold learns, for instance, when his daughter picked a tick in the summer of 1986 . Before his wife could get a feedback from the pediatrician's office, he had got the information he needed from the WELL and had removed the tick. The WELL, like several other Internet Relay Chat (IRC) groups, provides information and emotional support for its Netizens. As a setting of the conversations, which we reflect on in this essay, WELL is explained in its home page as “... a place made of words, an extraordinary word palace with thousands upon thousands of topics of interest. There are members (sic) pages and WELL conferences you can look at without a password, but the bottom line is that members know it's the interactive 
experience that engages, informs, enrages and transforms us" and metaphorically as "a cluster of electronic towns on the Net, inhabited by people from all over the world". Metaphorization is an important strategy in the conceptualization of WELL and its activities. In fact, on the home page, the acronym WELL shifts to the real common noun "well" that contains water, and in some other WELL discourses it re-emerges as a modifier that is affixed to the headword to form a compound word, as in "WELLbeing," which presents a fusion of virtual identity and imagined needs of the WELL Netizen (see Figure One below).

\begin{tabular}{|l|l|l|}
\hline Configurations & WELL semiosis & Strategy \\
\hline Being healthy & Be/ing WELL, WELLbeing & $\begin{array}{l}\text { Linking identity to wellness } \\
\text { "Human being? } \\
\text { WELLbeing" ? being well }\end{array}$ \\
\hline $\begin{array}{l}\text { Concern for the welfare of } \\
\text { community members }\end{array}$ & WELLbeing & WELLbeing? wellbeing \\
\hline Swimming & "Plunge into the WELL" & $\begin{array}{l}\text { WELL ? (water) well } \\
\text { Netizenship as a refreshing } \\
\text { experience }\end{array}$ \\
\hline
\end{tabular}

Figure 1. Configurations/Characteristics of WELL Netizenship

Water sustains human life, and so the metaphor of "well" is humanistic, even though the idea of "Plunge IntoThe Well" found on the home page might present a paradox about suicide! Plunging into a swimming pool is not the same thing as plunging into a well full of water. Nobody swims in a well, unless the person is not well.

However, WELL as setting of the conversations, provides a refreshing context of insight, information, and social support. Language is an important medium of the generation and transmission of insight in the virtual community - which is why WELL is configured as "a palace made of words" -and how this language is manipulated is also important. According to Rheingold (1993), "In the virtual community I know best, elegantly presented knowledge is a valuable currency. Wit and use of language are rewarded in this medium, which is biased toward those who learn how to manipulate attention and emotion with the written word. Sometimes you give one person more information than you would give another person in response to the same query, simply because you recognize one of them to be more generous or funny or to-the-point or agreeable" (http://www.rheingold.com/vc/book/2.html). One finds this inclination to the scribal and unfettered production and sharing of ideas in the metaphorical configuration of chat groups in the WELL community, for instance "Inkwell.vue", from where some of the data used in this paper have been drawn. An inkwell, ordinarily a piece of stationery, could be seen as an important element in the medium of writing. The metaphorical inkwell (obviously a re-invention of the virtual community "WELL" as a writing community) as a semiotic in electronic cyber writing suggests the perception of the chatroom as a medium of intellection itself, not really a location or a container.

The humanistic concern with the intellect - the unfettered generation of ideas and 
critical thinking - characterizes Netizenship. In this regard, Hauben and Hauben (1997:45) have observed as follows:

Net society differs from off-line society by welcoming intellectual activity. People are encouraged to be thoughtful and to present their ideas to the Net. People are allowed to be intellectually interesting and interested. This intellectual activity forms a major part of the online information that is carried by the various computer networks. Netizens can interact with other people to help add to or alter that information. Brainstorming among different types of people produces robust thinking. Information is no longer fixed commodity or resource on the Net. It is constantly being added to and improved collectively. The Net is a grand intellectual and social commune in the spirit of the collective nature present at the origins of human society.

In the context of this humanistic or humanizing world, the role played by language is very crucial and worthy of intellectual reflection. Two issues interlock here: one is the issue of the preferred language(s) of cyber interaction, while the other is how stylistic practices of the Netizen in the preferred language promote humanistic interests and open up interesting debates about language as creative behaviour.

The issue of the chosen language of cyber interaction has been at the heart of the debate about the Net as another context of domination and infringement on rights. Some scholars have argued that the current status of the English language as the language of the Net exposes the lie in the claim that the Net, as a medium of globalization, promotes democracy and freedom. For them, the role played by English clearly suggests linguistic imperialism. These scholars are asking: As "the default language of the electronic world" (Cairncross 2001:xvi), how much of free creative thinking does English allow to its non-native or nonspeakers who find themselves also caught in the Net? Cairncross (2001), linking the dominance of English with the special role given the language in many countries - either as the dominant or official language - however identifies the dominance of Englishspeaking Internet hosts and users in America as a major factor:

The dominance of English on the Internet follows inevitably from the dominance of Americans among Internet hosts and users. As the proportion of non-native English speakers using the Internet has risen, other languages have become more widely used. But English will probably remain disproportionately important on the Internet, creating a large new category of English users: those who can write the language colloquially but cannot necessarily speak it. (p.281)

Statistics provided by OECD and cited by Cairncross (2001:281), shows that English, as far back as 1999 , had $78.3 \%$ of the websites on the Internet, while French had 1.2\%, German $2.0 \%$, Chinese $0.6 \%$, Spanish $1.7 \%$, and all other languages $13.7 \%$.

Apart from the high percentage of (North) American English-speaking people that use the Internet, it has been observed that the very nature of the Internet already calls for an "international lingua franca", a "cyberspeech", which English automatically claims, being the most international. In addition, in designing personal computers and the Internet itself, 
the American Standard Code for Information Interchange (ASCII) has been used, which again readily privileges English (Warschauer, 2001). However, this Internetization of English faces serious challenge from various linguistic nationalisms that have coincided with the use of the Internet as a tool for liberation. Warschauer (2001) has suggested that the percentage of dominance that English has on the Internet is likely going to decline, especially because “...web browsers are being adapted for an increasing number of languages and character sets. Thus, while Internet users around the world still must use English for global communication, today they are increasingly turning to their own language to reach websites or join discussions in their own country or region". The recent designing of a multilingual Nigerian keyboard in the United States is one of such developments that challenge the authority of English in CMC.

The choice of linguistic code is therefore an important issue for the construction of identity of a given virtual community. Although language has no natural relationship with identity - whether ethnic, racial, gender, or religious identities - it appears to have special role to play in the identification of the way virtual communities perceive their interests and relationships. Warschauer (2001) has rightly observed that:

It is not surprising that language and dialect have assumed such a critical role in identity formation. The process of becoming a member of a community has always been realized in large measure by acquiring knowledge of the functions, social distribution, and interpretation of language (Ochs and Shieffelin).... In the current era, language signifies historical and social boundaries that are less arbitrary than territory and more discriminating (but less exclusive) than race or ethnicity.

On the Internet, he argues, one may not easily tell whether another is rich or poor, male or female, Black or White ${ }^{3}$, but one can easily observe the language or dialect another is using, and inevitably attach significance to such a code. Warschauer believes that the preference that some virtual communities have for their real world local dialects or languages suggests a gradual shift from globalization to "relocalization". Perhaps there is a problem of terminology here; "relocalization" may suggest wrongly a return to the boundary-setting localism. What the use of local dialects or languages on the Net suggests is the shift from globalization (that privileges a given type of speech) to glocalization, which means the global recognizing and reconciling with the local. In this case, the rights of other languages (and by implication the rights of their speakers) are protected. Instead of the Internet predicting and actualizing the death of other languages, it turns to revitalize and promote them. A personal experience as a moderator of a Yahoo group, Otu Umunna, which is located at http://groups.yahoo.com/group/out_umunna, confirms the point being made above. Otu Umunna Group is, as explained on the homepage, "a community of Igbospeaking staff of the University of Ibadan, an intellectual recuperation of Nzuko Umunna in Igbo culture. It provides a context for the voice of the kinsperson to be heard in the community, propagating the idea of "Onye kwue uche ya", which encapsulates democratic freedom and tolerance traditionally respected in Igbo culture". Speaking and writing Igbo language within the community is therefore highly welcomed, especially as means of 
consolidating group solidarity and promoting Igbo cultural values. Some members have thus constantly drawn my attention to the need to post messages in Igbo. Although I have always had to wrestle with my computer, which, based on its non-recognition of Igbo words, tries to automatically re-write "Otu" each time as "Out", it has become something of a stylistic fun for me to make postings in Igbo or deliberately code-mix to preserve the beauty of Igbo figurative expressions, to represent linguistic hybridity, to play with my bilinguality, and sometimes to play the politics of exclusion.

Wrestling linguistically with the artificial intelligence of the computer and the Internet becomes a challenge that speakers of marginalized languages must accept, and seek to register their presence in the virtual market of free speech. Instead of marginalizing, therefore, the Net accommodates and is transformed in the process.

Indeed, the shift from the use of English as cyberspeech to other languages among some virtual communities is not just an act of linguistic nationalism but also a pursuit of linguistic humanism, which in this case is part of the whole concept of cyberhumanism - the pursuit of humanistic principles in cyberspace. The pursuit of linguistic humanism is based on the argument that, whereas groups in multilingual settings use their languages to construct their separate identities, privileging one or some of the languages could have far-reaching political and economic consequences. As Adegbija (1997) has pointed out, speakers of small population languages may be denied opportunities in the society based on the difference of their languages. In other words, discrimination against the group or disempowerment of the group may be transferred to the language used by the group, and vice versa. The systematic destruction or assimilation of the group is pursued in the killing, neglect, or discouragement of the language or dialect associated with the group.

It is indeed the case that belonging to a virtual community also means accepting the privileged language of such community: as it is linguistically in real life (IRL), so it is in the unreal life, one might say. With reference to WELL, English remains the language of the community, even though many of its members are not native speakers of English. What appears rather more significant in the case of WELL is the way a new diatype, which expresses peculiar community interests and perceptions, has gradually evolved. New words, originating from the acronym "WELL", are being coined and used by members as analyzed earlier, as part of the creative response to language generally. Of course, this repertoire grows within the metalanguage of cyber life which members had had to acquire and use. A WELL member, so to say, is then a cyber poet, having acquired some cyberspeech, and being predisposed to enrich the community-specific semiosis.

Apart from the choice of linguistic code, which I have argued should be seen in relation to identity construction and humanism in the virtual community the specific goals and ideologies pursued by the virtual community have implications for the style of language used in that community. At this point it should be noted that virtual communities have diverse ideological interests: virtual hate communities, for instance, do not use the same type of style as religious or evangelical virtual communities. Hate groups are already always characterized by a verbalization of their prejudices. Religious groups that aim at winning converts through the preaching of salvation and righteousness tend to avoid 
expressions of prejudice, except, maybe against unnamed "workers of iniquity", which is perfectly in line with their own pursuit of fighting against the devil. Language and ideology inform and condition each other. In fact, every use of language is ideological, and it is those uses of language that mask ideology, or pretend not to be ideological, that one should be more cautious in consuming.

Howard Rheingold, in his article entitled "The Art of Hosting Good Conversations Online" (http://www.rheingold.com/texts/artonlinehost.html), outlines the following as what online hosts want to achieve:

- The ongoing goal is civil discourse: all kinds of people having conversations and arguments about a variety of subjects and treating each other decently.

- Authentic conversations -from the head, the heart, and the gut.

- A feeling of ownership. Participants become evangelists.

- A spirit of group creativity, experimentation, exploration, good will.

- A shared commitment to work together toward better communication, better conversations. If this is achieved, nothing else is needed.

- A system where people figure out where the conversation is going, by themselves, and settle conflicts among themselves.

- A place where everybody builds social capital individually by improving each other's knowledge capital collaboratively.

Virtual conversations therefore require politeness, at least based from the fact that one of the major goals is to cultivate good human relations, to build friendship, to help the other, and eventually be helped by others someday. From a pragmatic perspective, interactants in a virtual community are expected to do facework, i.e. to use strategies and linguistic tactics that only promote the face wants of interlocutors, something that is particularly necessary because the backgrounds and real social statuses of the interlocutors may not be fully known. The tendency therefore would be to minimize threats to face wants by avoiding verbal behaviours that may be processed as offensive. Facework strategies suggested by Lim and Bowers (1991) are expressions of solidarity, approbation, and tact. In the Lim-and-Bowers framework, face wants are wants that individuals have, which require that others cater for in communicating with them. These wants are classified into Fellowship Face, Competence Face, and Autonomy face. Fellowship Face refers to "the want to be included" or to be seen as an acceptable member of a community, while Competence face refers to the want that one's abilities be recognized and respected. Autonomy Face is the want to be left undisturbed or not be imposed upon (Lim \& Bowers, 1991:420). Fellowship Face, which correlates with Abraham Maslow's "Love and Belongingness Needs" (Maslow, 1943 [1971]), is promoted by illocutionary acts such as praising, thanking, and commending, and threatening by negatively oriented acts like criticizing, condemning, and expressions that alienate. Netizens in a particular virtual community, for instance WELL, would obviously expect other members to treat them as insiders, who share values with every WELLite. Rheingold (1993) has pointed out that 
older WELLites see it as an obligation to assist newcomers to be properly socialized (WELLized, or to be WELL, one could say) and be integrated into the WELL community. Such WELLization is, in a sense, a process of education on the ideological outlook of the virtual community. I believe this same process goes on in many other virtual communities.

Rheingold, in this regard, has argued that a good online discussion should:

- Enable people to make contact with other people.

- Enable people to entertain themselves rather than being just the passive consumers of canned entertainment.

- Enable people to create a gift economy for knowledge-sharing.

- Create conditions for ongoing collaboration that return individual effort with a whole that is greater than the sum of its parts.

- Provide a way for people to get to know each other beyond their usual masks.

- Make newcomers feel welcomed, contributors valued, recreational hasslers ignored.

It is important for the newcomer to feel welcomed, for welcome psychologically motivates and individual, suggesting that such an individual has some relevance within the context of welcome. A place of welcome is a place to go to, to depend on, to trust, and to assist. People come to the virtual community with needs they want satisfied, and fellowship or belongingness is one of the most important of these needs. As a matter, the economic and social pressures in the contemporary world are driving people more and more into isolation. Community in the modern world is collapsing, and so the emergence of the virtual community seems to compensate somehow for this growing alienation and anomie. Rheingold in his The Virtual Community writes: "Perhaps cyberspace is one of the informal public places where people can rebuild the aspects of community that were lost when the malt shop became a mall. Or perhaps cyberspace is precisely the wrong place to look for the rebirth of community, offering not a tool for conviviality but a life-denying simulacrum of real passion and true commitment to one another" (http://www.rheingold.com/vc/book $/ 1$.html). Whatever may be the case, the cyberspace, represents the longing for community, whether it is utopian or not. Similarly, distance is erased in cyber interaction, as suggested by the title of Frances Cairncross' book, The Death of Distance (2001). Social and demographic variables of class, gender, age, and religion become of little effect, except in cases where virtual communities are specifically defined along those lines of difference.

The relationship of mutual assistance suggests that anybody in the virtual community needs everybody: nobody is dispensable. This creates an obligation of catering for not only the fellowship Face but also the Competence and Autonomy Face wants. Nobody bosses the other, and everybody matters in building and sustaining the community. This takes us to the importance of tenor (role relationship and what language is used in doing) in interactions in the virtual community. Virtual conversations, such as the type in WELL, are organized around certain topics, and members post their contributions. Thus, the exchange structure is the same INITIATION?RESPONSE?FOLLOW-UP that we have in 
natural conversations. Initiators or "speakers", who are usually known as WELLites (or if they are new members they introduce themselves to minimize social distance) may introduce issues to be examined, seek clarifications, make specific requests on how to solve some problems, etc. Responders, who are also WELLites, base their responses on existing WELL relationship, and so address initiators as familiar interlocutors. Familiarity is an important element of tenor in discourse; in the context of WELL interactions, it underlies the usual use of informal and cordial language (although this cordiality may depend on the way the initiator of the discourse postures in the conversation). Compare, for instance, the kind of response given to Farooq Khan and his New Civilization's invitation for incisive debate on Islamic political thought (\# 355) by "all mouse-and-gui about it" (factoid) (\#356) and that given to Sharon O'Donnell (Sharon-rpo) \#364 by Gail Williams (gail) \#365 in Appendix B. Farooq seems to come to the conversation with a language and ego that are out of place. Moreover, the invitation presupposes a "Western" intellectual weakness in relationship to Islamic thought, a presupposition that infringes on all the face wants. Factoid is therefore interested in deflating Farooq and tries to do this by identifying him as an impostor: "Mack ... hopeless multimedia dilettante posing as a web consultant/ blogger / writer / photogger". Sharon-rpo, who comes with all humility ("Hi, I'm Sharon, and I'm a struggling writer with a gnarly organizational problem with the second draft of my second novel. Need help / hints from those who've gone before. Can anyone help? Just for a minute? THANKS!!" Such a request would hardly be ignored or turned down, considering the way the requester has (1) recognized the competence of those from whom assistance is sought ("those who've gone before"); (2) recognized that her act of requesting infringes on somebody's Autonomy Face - the want not to be disturbed - for it takes time to help, and so she is just asking for "a minute", unlike Farooq who assumes that WELLites have no other thing to do than just debating Islamic political ideas which he had already given the West a swipe for not recognizing; and (3) makes effort to thank the requestees. Sharonrpo, "speaking" in the normal lore of asking the feeling other, is tactful and mindful of infringing on relationship, while Farooq is not. Gail's advice is therefore is appropriately supportive.

It is interesting that, apart from factoid's response to Farooq, the trouble-shooting Farooq is generally ignored by other WELLites - an avoidance strategy that enables the chat group to keep to topics that promote WELLbeing ${ }^{4}$ - as the conversation now shifts to factoid's link with New Haven, and old virtual friends re-discover one another, the language of the conversation becoming cordial. Tenors within a given virtual conversation may intersect with tenors of previous encounters, and of course may be affected by such previous encounters. Obviously, when Farooq comes back in another conversation, he would be remembered for his Islamic political thought invitation, unless he changes his identity.

Identity and identification are very important in managing tenor in WELL conversations. Although each WELLite, as we find above, has a pseudonym, this pseudonymity does not imply general anonymity. Rheingold has pointed out that: "One important social rule was built into the software that the WELL lives inside: Nobody is 
anonymous. Everybody is required to attach their real userid to their postings. It is possible to use pseudonyms to create alternate identities, or to carry metamessages, but the pseudonyms are always linked in every posting to the real userid. The original PicoSpan software offered to the WELL had an option for allowing users to be anonymous, but one of Stewart Brand's few strong influences on system design was to insist that the anonymity option should not be offered" (http://www.rheingold.com/vc/book/2.html). Yet the art of masking appears to be an important part of interaction in the virtual community; it makes Netizens more cautious; it is part of the persistence of Security Need that individuals have and do pursue, as Maslow (1943) provides. Rheingold, again, explains that masking is "part of the grammar of cyberspace": "... the authenticity of human relationships is always in question in cyberspace, because of the masking and distancing of the medium, in a way that it is not in question in real life. Masks and self-disclosures are part of the grammar of cyberspace, the way quick cuts and intense images are part of the grammar of television. The grammar of CMC media involves a syntax of identity play: new identities, false identities, multiple identities, exploratory identities, are available in different manifestations of the medium" (http://www.rheingold.com/vc/book/5.html).

Rheingold in "The Art of Hosting Good Conversations Online" has pointed out that not all conflicts are avoidable, and that sometimes, conflicts should becomes means of reminding Netizens about the value of Netiquette. He advises online hosts: "If a conflict is important enough to have its hooks into the attention of a large number of members of the population: use it as an occasion to remind people that civility is essential if discussions are to cohere into communities. Conflict tests the boundaries of the community". Conversations in the virtual community sometimes break down when values are confused, or when human feelings clash. But such conflicts are to be expected in a human community, and do serve as means of building stronger relationships and healthier community. Morin (1999:49) has cautioned that communication in itself does not necessarily make human beings understand one another: "We must not forget that no technique of communication - from telephone to Internet - can in and of itself bring understanding. Understanding cannot be digitalized". He therefore suggests that we seek greater tolerance:

The ethics of understanding demands that we discuss and refute instead of damning and excommunicating. Confining in the notion of treachery something that pertains to broader intelligibility is a refusal to recognize error, misdirection, ideology, excess.

Understanding neither excuses nor accuses. It teaches us to refrain from condemning hastily, irremediably, as if we ourselves had never erred. If we learn to understand before condemning, we will be on our way to humanizing human relations. (1999:52)

It is principally this quest for understanding through tolerance and freedom of speech that the WELL seeks and encourages. It should be noticed, for instance in Appendix A, that the use of obscene language ("Holy Fucking Shit!") by Cliff Figallo (fig) in his response (\#201) to Rheingold's posting ( $\# 200$ ), is generally tolerated, a clear case of granting one the freedom to use one's idiolect, even when ordinarily it infringes on Autonomy Face wants of some other Netizens. Human beings tend to adopt the Polyanna Principle of 
focusing on the bright side of experience, and so may perceive dysphemistic expressions as infringing on the right to be left undisturbed. As a familiar figure, Figallo's insistence on speaking his own way is tolerated by other WELLites. Thus, we find that in servicing tenor in the virtual conversation, humanism plays a great part.

The mode of the discourse - specifically the electronic writtenness that pretends to be a spokenness - has a special impact on the style of language used by WELLites in the community. Cyber writing mimics orality, and there are cases where we find that efforts are made to compensate for the loss of forms of behaviour that normally contribute to meaning-making in face-to-face interactions. In Appendix A, for instance, wish you the very beat, who is otherwise called "tinymonster" in making a contribution simply writes "< smiling >", providing readers ("listeners") with a description of the supposed nonverbal reaction. But generally, the style of the conversations tends towards orality as much as possible, particularly as an attempt to live up to the dream of being a CONVERSATION. Consider, for instance, a response like "Sorry, an extra "rather" in there", from Steve Silberman ("digaman") in \#43 in Appendix C. Digaman is certainly tactful in his self-repair, as he tries to avoid phrasing his response in a way that would adversely affects his Competence Face.

The language of most of the WELL conversations is also chatty and informal, which again relates to the nature of non-formal relationship desired by the interactants. Rheingold (http://www.rheingold.com/vc/book/1.html) explains that the WELL is also about:

... the pleasure of making conversation and creating value in the process. Although all these responses were originally typed on a terminal or computer keyboard, and are available for people to read long after they were typed, the postings in a computer conference are experienced by those who read and write them as a form of conversation as well as a form of publication. In the case of the WELL, it's a conversation in which 16 percent of the people contribute 80 percent of the words, but many people are listening invisibly and all are free to join. In that sense, there's a theatrical element to this medium-written conversation as a performing art. One of CMC's distinguishing characteristics is the way it mixes aspects of informal, real-time communication with the more formally composed, write-once-read-forever mode of communication.

In real life, conversations are not entirely informal, or entirely formal, otherwise they would be unbearable.

Further, the virtual conversations follow the usual turn-taking pattern that we find in natural conversations, this time even made inevitable by the fact that once a posting has been made, one has taken one's turn, unless one has made an error and quickly acts in time to correct it through another posting before another person takes a turn. This could be seen in Digaman's self-repair in Appendix C. The system prevents interruptions, since only a posting comes in at a time. So, it appears that virtual conversations have taken care of interruption as a face-threatening behaviour, making turn taking in exchanges a norm. Moreoever, a previous posting is copied as a tail in the response, a practice that facilitates memory and reference. 
The value of language in building human community and in making the community work better is clearly shown in virtual conversations such as found in the WELL community. The pursuit of human interest, in the measure of freedom of creativity and expression, in the encouragement and support given to others, and even in correcting others politely or making them keep to Netiquette (to prevent the idea of normlessless, is highly evident in the WELL interactions. Perhaps, one may not draw exactly the same conclusions about some other communities, for instance ALT-X, which generally pursues an iconoclastic tradition, making normlessness a norm. The way conflicts are managed in WELL is also not the same in some other communities.

Virtual communities like the WELL provide an invaluable research milieu for linguists and literary scholars. They present useful data on patterns of behaviour that the New Information and Communication Technologies, especially the Internet, have generated, and which contemporary scholarship cannot afford to overlook. Above all, virtual data throw up issues about the challenge of humanism in the market place of ideas. A "word palace" poses a great challenge to human identity and mediations of such identities, relationships, and goals. A "word palace" simulates and communicates power and power struggles, even when it appears to either minimize or transform it to co-operation. Co-operation is a mode of power and means of reinventing power. Thus the WELL Netizen builds power through discourse and language that cater for WELLbeing.

\section{Notes}

1. Cyberspace refers to "the conceptual space where words, human relationships, data, wealth, and power are manifested by people using CMC technology" (Rheingold, 1993, http://www.rheingold.com/book/intro.html). CMC is the acronym for Computer Mediated Communications.

2. For a detailed discussion of the theoretical approaches adopted by these scholars, see Stevick (1990).

3. Rheingold (1993) has similarly asserted as follows: "Because we cannot see one another in cyberspace, gender, age, national origin, and physical appearance are not apparent unless a person wants to make such characteristics public. People whose physical handicaps make it difficult to form new friendships find that virtual communities treat them as they always wanted to be treatedas thinkers and transmitters of ideas and feeling beings, not carnal vessels with a certain appearance and way of walking and talking (or not walking and not talking)". (http://www.rheingold.com/vc/ book/1.html).

4. It might be argued that the WELL is a reflection of Western domination of discourse that goes on in the global village - the Net being a typical context - if the response given to farooq is interpreted as unwillingness to accommodate non-Western (Islamic) issues in the chats. Farooq might not, after all, be a Muslim: perhaps he is merely trying to set a trap in the conversation, to test the temperament of the chat group on Islamic issues, to make the Netizens reveal how far they are still attached or detached from the cultural politics of real world citizenship. Furthermore, although ignoring him is a way of avoiding discussing issues that might not promote WELLbeing, it ironically amounts to an infringement on Farooq's fellowship face want (the want to seen as a 
desirable member of community), and, by extension, an undermining of the principle of being civil in discourse and allowing "all kinds of people" to participate in conversation, engage in "arguments about a variety of subjects", "treating each other decently", as enunciated by Rheingold (1998).

\section{References}

Adegbija, Efurosibina (1997): "The identity, survival, and promotion of Minority Languages in Nigeria". International Journal of the Sociology of Language 125: 5- 27.

Amerika, Mark (n.d.): "My Oblivion", Blackice. [http://www.altx.com/profiles/archives/philosophiction/myobli.htm].

Cairncross, Frances (2001): The Death of Distance. Boston, MA: Harvard Business School Press. Curran, C.A. (1976) Counseling-Learning in Second Languages. Apple River, Ill.: Apple River Press.

. (1978) Understanding: A Necessary Ingredient in Human Belonging. Apple River, Ill.: Apple River Press.

Gattegno, C. (1987) The Science of Education. Part I: Theoretical Considerations. New York: Educational Solutions, Inc. . (1988) On Being Freer. New York: Educational Solutions, Inc.

Hauben, M. (1995 [1997]): "What is a Netizen?" Preface to Netizens: On the History and Impact of Usenet and the Internet. Los Alamitos, California: IEEE Computer Society Press, ix - xi.

Hauben, M. and R. Hauben (1997): Netizens: On the History and Impact of Usenet and the Internet. Los Alamitos, California: IEEE Computer Society Press.

Hooker, R. (1996): "Humanism". World Civilizations/World Cultures. [http://www.wsu.edu:8080/ dee/WORLD.HTM].

Lim, Tae-Seop and Bowers, John Waite (1991): "Facework: Solidarity, approbation, and tact". Human Communication Research 17(3): 415-450.

Lozanov, G. (1979) Suggestology and Outlines of Suggestopedy. New York: Gordon and Breach. Maslow, Abraham (1943 [1971]): "A theory of human motivation". In R.V. Guthrie (ed.) Psychology in the World Today: An Interdisciplinary Approach. London: Addison-Wesley, $101-119$.

Morin, Edgar (1999): Seven Complex Lessons in Education for the Future. Trans. N. Poller. Paris: UNESCO.

Moskowitz, Gertrude (1978) Caring and Sharing in the Foreign Language Class: A Sourcebook on Humanistic Techniques. Rowley, Mass.: Newbury House.

Rheingold, Howard (1993): The Virtual Community: Homesteading on the Electronic Frontier. New York: Addison-Wesley. http://www.rheingold.com/index.html, accessed 10 February, 2006.

Rheingold, Howard (1998) "The art of hosting good conversations online". Rheingold's Brainstorms, http://www.rheingold.com/texts/artonlinehost.html, accessed 6 February 2006.

Stevick, Earl W. (1990) Humanism in Language Teaching: A Critical Perspective. Oxford: Oxford University Press.

[http://www.sil.org/lingualinks/LANGUAGELEARNING/BooksBackInPrint/onhumanis minlanguageteaching/humanism.pdf, accessed 12 December 2005]. 
Warschauer, Mark (2001) "Language, identity, and the Internet". Mots Pluriels 19 (October). [www.arts.uwa.edu.au/MotsPluriels/MP1901mw.html, accessed 12 December 2005].

\section{APPENDIX A: WELL Conversation, Topic \#240, Accessed 26 April 2005}

inkwell.vue 240: The WELL at 20, with Howard Rheingold, Cliff Figallo and friends \#200 of 210: Howard Rheingold (hlr) Thu 07 Apr 2005 (01:41 PM)

That was courageous of you, Gail. And yeah, I don't think David would have been happy in the position in the long run. A long ways upthread, Gail mentioned the WELL's reputation. I guess I've been around the world a couple dozen times since The Virtual Community was published -I put in 150,000 miles on UAL last year alone -and I'll certainly vouch for that. In many ways, I think the WELL's fame is the result of Stewart's marketing genius - no budget for advertising, but free accounts for journalists (that's how I got here, via a MicroTimes article). The folks who made the Media conference a central watering hole for technologyminded journalists should share that credit. Certainly, this isn't the oldest community(Metanet, for example), and with 100,000 newsgroups and uncounted listservs, message boards, chat tooms, online gaming communities, the WELL is far from the only one. But with all the changes, a continuity of intellectual tradition is worth applauding -there's still plenty of wit and wisdom, irreverence and lore, intellect and smartassery, and, yes, community spirit to be found here.

We used to fear that the WELL would die. Having been through the deaths of a couple of communities in the past decade, I now know that you couldn't kill the WELL if you tried. If the servers turned to lime jello tomorrow and/or Salon went under and/or any other doom scenario, I am willing to bet that software, server, and (bickering) organizing committee(s) would be on the case within minutes.

I have no doubt that the WELL will outlive all those whose words are here now. You there in the 22nd century -am I right, or what?

inkwell.rue 240: The WELL at 20, with Howard Rheingold, Cliff Figallo and friends \#201 of 210: Cliff Figallo (fig) Thu 07 Apr 2005 (02:02 PM)

You're right, Rheingoldian One. The WELL would complete the circle that began with BBSs. It would be run on a PC in someone's basement.

I was in such trouble with so many people by the time Gail describes that it all becomes a blur thinking about it. Hell, even David Hawkins walked out and, to my utter astonishment, refused to return to his job.

Holy Fucking Shit! We were not only sysopless, I'd been rebuked by one of the precious elders of the community.

And having my wife-to-be working for me during that time did not lead to the warm fuzzies on the homefront. The social chaos of that time,combined with the technical confusion and ownership juggling just proved how truly indestructible the WELL had become.

Maybe the Loma Prieta earthquake was the high point of my years there. It sure opened the collective heart and made us appreciate our being connected. It was followed immediately 
by the Mandel Meltdown so meticulously examined in Katie's article and book. And then things started tumblin'.

So, what's our next momentous caper, gang? Shall we lead the world into the post peak oil years?

inkwell.vue 240: The WELL at 20, with Howard Rheingold, Cliff Figallo and friends \#202 of 210: David Gans (tnf) Thu 07 Apr 2005 (05:09 PM)

We're restoring Jerry Garcia in the basement right now.

inkwell.vue 240: The WELL at 20, with Howard Rheingold, Cliff Figallo and friends \#203 of 210: Uncle Jax (jax) Thu 07 Apr 2005 (06:01 PM)

As long as he doesn't dance and sing, "Puttin' on the Ritz".

inkwell.vue 240: The WELL at 20, with Howard Rheingold, Cliff Figallo and friends \#204 of 210: Peace, order and good government (paulbel) Thu 07 Apr 2005 (06:03 PM)

And he's going to pitch for the Hoboken Zephyrs.

inkwell.vue 240: The WELL at 20, with Howard Rheingold, Cliff Figallo and friends \#205 of 210: Gail Williams (gail) Fri 08 Apr 2005 (12:01 AM)

We're down the the home stretch of this conversation, which is slated to run through noon Friday.

inkwell.vue 240: The WELL at 20, with Howard Rheingold, Cliff Figallo and friends \#206 of 210: John Payne (satyr) Fri 08 Apr 2005 (10:01 AM)

Heh! I've gotten caught up (and technically over my head) in how the Well's software (user experience) could be improved more than once, most notably having started a largish set of topics in < meta. >, mostly during July, 2000, the majority of which have since been killed.

These mostly related to the organizational structure of topics and conferences, not something that could easily be changed, nor that could be changed obviously and abruptly without ripples of resistance among users.

Poor timing on my part, no doubt. Our parent company, Salon, was struggling for its survival, and any schemes that meant new investment were all but out of the question.

I haven't exactly changed my mind about those ideas, but I've lost most of my attachment to them, and don't now have time to spare to get involved with implementing them, even if I did have the chops, which is doubtful.

PicoSpan is as it is in no small part because of what was practical, given available hardware, twenty years ago, and if it were being designed from scratch today it would be very different. But, you know, it really *does* work very well, and it's really not so hard to use once you get used to a few basic commands and they start to roll off your fingertips without really having to think about it. 
I can't speak to Engaged, since I've hardly used it (not at all recently),except for the limited version through which this conference and $<$ pre. vue. $>$ are world-readable, but based on what others have said there's a gradual drift towards preferring it. Certainly it's easier for new users to learn. (See note below.)

There's a lot that *could* be done to fill out the possibilities of user interaction, but, as $<$ gail > was at some pains to point out to me a few years ago, there's a core user experience here that shouldn't be messed with, and changes should therefore be approached with due caution. It's amusing to think that we might have undergone a role reversal on this issue over the intervening time. ;-)

Note: I use the links that Engaged automates in my posts as a matter of principle, even though I'm not logged in via Engaged myself. Not only do they provide added utility to those using Engaged, but they provide a standard format for certian references that, by now, most PicoSpan users recognize and readily interpret, and in some cases their content can be pasted into the PicoSpan command line with no editing.

inkwell.vue 240: The WELL at 20, with Howard Rheingold, Cliff Figallo and friends \#207 of 210: David Gans (tnf) Fri 08 Apr 2005 (02:45 PM)

Our next interview has taken center stage, and this is the moment when the Inkwell team thanks all our participants for their time and energy.

So: thank you all for being here.

I also want to say that the conversation does not have to end -and I hope it doesn't. All of you are invited and encouraged to continue.

inkwell.vue 240: The WELL at 20, with Howard Rheingold, Cliff Figallo and friends \#208 of 210: Low and popular (rik) Fri 08 Apr 2005 (02:48 PM)

It's been going on for 20 years now. Why stop now?

inkwell.vue 240: The WELL at 20, with Howard Rheingold, Cliff Figallo and friends \#209 of 210: wish you the very beat (tinymonster) Sat 09 Apr 2005 (11:29 AM)

$<$ smiling >

inkwell.vue 240: The WELL at 20, with Howard Rheingold, Cliff Figallo and friends \#210 of 210: John Payne (satyr) Sun 10 Apr 2005 (10:18 AM)

<pre.vue.>'s Question of the Week, now running for a second week, is What would you miss the most if the Well wasn't here?

$<$ pre.vue.57.1856-> will take you directly to where it starts. 


\section{APPENDIX B: WELL Conversation, Topic \#, 19 April 2005}

inkwell.vue 3: Hello, my name is and I am a

\#355 of 365: Farooq Khan (farooq) Mon 11 Oct 2004 (08:07 AM)

\section{New Civilisation Presents}

Islamic political thinking, hitherto unrecognised in the western world, and invites honest incisive responses. It is a unique forum,offering to bring together divergent views and serve as a crucible for all shades of political thought.

We believe that the old labels of left, right and centre on the one hand and fundamentalist and moderate on the other are now inadequate.

A fresh objective forum has now come of age, where the world's thinkers can explore the prospect of alternative solutions to common political problems.

We have thereby created a timely window of opportunity within a polarised post-secular world for the emergence of new voices of requisite reason.

$<$ islam.ind.25.5>

inkwell.vue 3: Hello, my name is and $\mathrm{I}$ am a

\#356 of 365: all mouse-and-gui about it (factoid) Wed 20 Oct 2004 (01:37 PM)

Mack ... hopeless multimedia dilettante posing as a web consultant/blogger/writer/photogger

inkwell.vue 3: Hello, my name is and I am a

\#357 of 365: Not really Batman at all (tinymonster) $\overline{\text { Wed } 20 \text { O }}$ ct 2004 (01:54 PM)

Welcome, (factoid)! Born in New Haven, CT, huh? I lived near there for years (and my dad still does)!

inkwell.vue 3: Hello, my name is and I am a \#358 of 365: all mouse-and-gui about it (factoid) Thu 21 Oct 2004 (09:45 AM)

I keep missing the annual flameout of the foliage, sadly. (FTR, been on the WELL since '96, but just wanted to give a shout-out here)

inkwell.vue 3: Hello, my name is and I am a

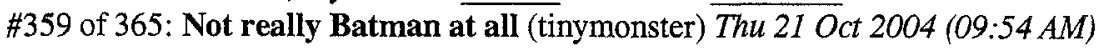

(Yeah, I'd seen you elsewhere....)

inkwell.vue 3: Hello, my name is and I am a

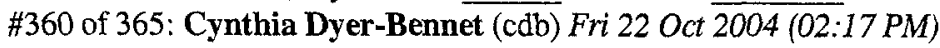

hey there, factoid, good to see your login here.

inkwell.vue 3: Hello, my name is and I am a 
\#361 of 365: all mouse-and-gui about it (factoid) Mon 25 Oct 2004 (09:22 AM)

Just jumped in at the Christian's interview this morning. Hope I didn't make too much of a mess.

inkwell.vue 3: Hello, my name is and I am a

\#362 of 365: Cynthia Dyer-Bennet (cdb) Tue 26 Oct $\overline{2004(10: 34 ~ A M)}$

not at all...

inkwell.vue 3: Hello, my name is and $I$ am a

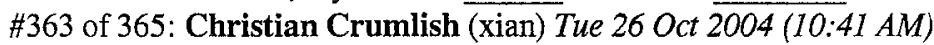

the messier the better

inkwell.vue 3: Hello, my name is and $\mathrm{I}$ am a

\#364 of 365: Sharon O'Donnell (sharon-rpo) Tue 19 Apr 2005 (06:21 AM)

$\mathrm{Hi}, \mathrm{I}$ 'm Sharon, and I'm a struggling writer with a gnarly organizational problem with the second draft of my second novel. Need help / hints from those who've gone before. Can anyone help? Just for a minute? THANKS!! sharonrpo@netzero.com

inkwell.vue 3: Hello, my name is and I am a

\#365 of 365: Gail Williams (gail) Tue 19 Apr 2005 (08:00 AM)

Sharon, also try the < writers. > conference. A good place to get to know writers and offer mutual aid and support.

\section{APPENDIX C: WELL Conversation, Topic 243, 26 April 2005}

inkwell.vue 243: John Einarson, "Mr Tambourine Man"

\#37 of 47: Steve Silberman (digaman) Mon 25 Apr 2005 (03:27 PM)

Thanks, John.

inkwell.vue 243: John Einarson, "Mr Tambourine Man" \#38 of 47: John Einarson (johneinarson) Mon 25 Apr 2005 (03:53 PM)

There have been three Gene Clark tribute compilations released in the last couple of years by young artists who have been inspired by Gene's body of work. Most are alt. country/indie outfits like The Kennedys, Steve Wynn, Buddy Woodward, Sid Griffin, but some are well known like John Jorgenson (hotshot guitarist in the Desert Rose Band), Nashville singer/songwriter Bill Lloyd, and Carla Olson (one CD was recorded by Australian artists). 
Many of the alt. country recording artists today like Mark Olson and Victoria Williams cite Gene's direct influence on them. As Victoria Williams told me, "The Fantastic Expedition of Dillard and Clark was a great record! I think we learned every song on that album. When I started playing music in Louisiana we did Dillard and Clark songs, and Gene Clark's songs, and, of course, Gram Parsons. They sort of gave me that inspiration to think, 'Well I'll write songs too then.' I got to meet Gene Clark when I first moved to California. He was so wonderful. He was one of these people whose music I loved back in Louisiana. I met him at the Whisky. I was in awe of him". Adds Mark Olson, "When you listened to Gene Clark, you realized you were listening to someone who could really sing and write well. For me, listening to that first Dillard and Clark album shoved me more in the folk direction".

There is no doubting the influence Dillard and Clark had on the evolution of country rock in the latter 60 s to early 70 s (pre-Eagles). When I was researching and writing my book "Desperados: The Roots of Country Rock" so many of the pioneers of that genre declare Dillard and Clatk to be the most authentic country-rock amalgamation of all the artists attempting that merger at the time. Certainly Chris Hillman insists that Dillard and Clark were far more innovative and influential at the time than the Flying Burrito Brothers (and insists Gene was a far better songwriter than Gram Parsons), as does Rusty Young from Poco, Mike Nesmith, and John McEuen from the Dirt Band, just to name a few. Dillard and Clark are an important $\operatorname{cog}$ in that wheel of what would become commercially acceptable by the mid $70 \mathrm{~s}$ with the Eagles. Don't forget that founding Eagle Bernie Leadon was in Dillard and Clark before the Burritos and learned songwriting from Gene.

While I' ve not been contacted directly by any current recording artists, that doesn' $t$ mean Gene's influence isn't still felt. I know that he is held in high esteem in the UK and younger bands like Teenage Fanclub have covered his songs. But more than just his existing songs, Gene's poetry and melancholy style remain an influence on songwriters today. Anybody who cites the Byrds as an influence knows about Gene's influence.

What is needed is a high-profile Gene Clark tribute CD or concert where some of those big name artists who revere Gene step up to the plate and pay tribute.

inkwell.vue 243: John Einarson, "Mr Tambourine Man"

\#39 of 47: Steve Silberman (digaman) Mon 25 Apr 2005 (04:18 PM)

Wonderful answer, John.

inkwell.vue 243: John Einarson, "Mr Tambourine Man"

\#40 of 47: John Einarson (johneinarson) Mon 25 Apr 2005 (05:09 PM)

Thanks Steve. Gene was inspired to compose "Eight Miles High" following the Byrds' hasty tour of England in August 1965. The band did not go over well and were lambasted by most of the press. In their defence, the five Byrds were exhausted from a rigorous US tour and suffering from colds/flu.

Back in the US in November, the Byrds were opening for the Rolling Stones in Pittsburgh when Gene and Brian Jones got together for dinner at their hotel and talked about that ill-fated Byrds UK tour. The germ of a song idea was planted in Gene's mind based on his conversation with Brian (Gene credited Brian for assisting with the genesis of the song in an interview once) 
and, back out on the road, he began developing the lyrics and chords. "I had an idea for some lyrics," stated Gene in a later interview, "and wrote them on a piece of paper during the conversation with Brian. Later on I found them in my jacket pocket on the tour bus. I took my guitar and started making up a melody for it. The initial idea was discussed on the plane over the Atlantic on our trip to England, but the actual writing of it started on a tour with the Stones when we were back in the States".

Gene played the rough composition to David (Crosby) and Roger(McGuinn) who then contributed to its completion, David with the line "Rain grey town known for its sound" and Roger the distinctive Ravi Shankar/John Coltrane-inspired guitar figure that would later be termed "raga rock", a precursor to acid/psychedelic rock. The Byrds had been listening to nothing else other than Shankar and Coltrane in their minibus on the road.

So the basic song (chords, lyrics) came from Gene describing their flight (hence the eight miles high reference although it was closer to six miles), landing, arrival in London, and culture shock the Byrds experienced. David added a line, Roger the unique guitar part and arrangement. So when the song was released, the credits were shared by all three equally (they still share the royalties equally). Gene acknowledged in several interviews that "Eight Miles High" represented the pinnacle of his Byrds songwriting experience because it was a collaboration between all three. David and Roger both agreed in interviews with me. "It was my favorite moment," says David. "It was when we actually started to come into our own".

The band cut two versions, one in late December at RCA studios and another in January at Columbia studios (ultimately the single version). Fans remain divided over which is the best version. Both have their merits (and both are on the reissued Fifth Dimension album if you want to compare them - the RCA version is a little more urgent)

Unfortunately when the single was released in March 1966 after Gene had already left the band, the title made some radio programmers uneasy. To them the "high" implied drugs, despite insistence from the group that it was about a plane ride. Many radio stations refused to play it and influential programming service Bill Gavin's Record Report banned the record. Why such an incredibly innovative record was kept out of the top ten (it should have been \#1) remains a travesty but that was the tenor of the times. "Eight Miles High" is a milestone in rock music's evolution pointing the way toward psychedelic rock a full year before.

Since Gene's death, the credits have been altered on subsequent Byrds releases to read McGuinn, Crosby, Clark, a move that has drawn ire from Clark associates.

inkwell.vue 243: John Einarson, "Mr Tambourine Man" \#41 of 47: from GENE HARROLD (tnf) Mon 25 Apr 2005 (06:41 PM)

Gene Harrold writes:

Hi John. Did you ask the surviving Byrds why Gene was left out of the Byrds box set sessions? I know there was tension due to the court case about the ownership of the Byrds' name... Gene had used it for his Byrds 'tribute' tour but he had shut it down by that time.. Just seems awfully petty to have left Clark out and what a lost opportunity!!

Thanks, Gene Harrold 
inkwell.vue 243: John Einarson, "Mr Tambourine Man"

\#42 of 47: Steve Silberman (digaman) Mon 25 Apr 2005 (06:43 PM)

Why such an incredibly innovative record was kept out of the top ten (it should have been \#1) remains a travesty but that was the tenor of the times.

inkwell.vue 243: John Einarson, "Mr Tambourine Man"

\#43 of 47: Steve Silberman (digaman) Mon 25 Apr 2005 (06:44 PM)

Sorry, an extra "rather" in there.

inkwell.vue 243: John Einarson, "Mr Tambourine Man"

\#44 of 47: John Einarson (johneinarson) Mon 25 Apr 2005 (07:52 PM)

The three Byrds at the time in 1990 - McGuinn, Crosby and Hillman - were mad at Gene and Michael for both doing their Byrds tribute shows and decided not to include them in the sessions for the new tracks on the box set. That was according to Chris Hillman. In retrospect he regrets that decision. At the time, though, it was a case of who has the right to use the Byrds name, not necessarily the legal right (as Michael won it in court, although David owns it now) but the moral right. The three believed that latter belonged to them. In court Gene was ruled the "lesser Byrd"; he turned that into a persona as Lester Byrd. So many vintage bands have run afoul of the name game with certain members going out under the collective banner. Sad.

I agree, Steve, that the "high" was likely a double entendre and an hip in joke played by the Byrds that, regretably, backfired.

inkwell.vue 243: John Einarson, "Mr Tambourine Man"

\#45 of 47: Steve Silberman (digaman) Mon 25 Apr 2005 (11:18 PM)

John, who was the best interview for the book? Who was totally unlike you expected? Who got away?

inkwell.vue 243: John Einarson, "Mr Tambourine Man" \#46 of 47: John Einarson (johneinarson) Tue 26 Apr 2005 (06:05 AM)

Good question, Steve. Actually I've got to go with David Crosby as the best and most unexpected interview. I've never interviewed David before although we've exchange the odd email. But when I contacted him regarding the Gene Clark book he made himself available for an in-person interview and arranged for me to meet up with him backstage between soundcheck and concert time when CSN played a show in Sioux Falls, South Dakota in April 2003 (it's about an 8-hour drive south for me in Winnipeg). When I met him backstage he was most gracious and accommodating allowing me as much time as necessary to ask him about his relationship with Gene. We conducted the session in his private dressing room. At one point he got teary-eyed recalling anecdotes about Gene and the other Byrds. Clearly there was and remains a strong emotional bond. The interview was honest, insightful and revealing. David was nothing like what I had expected. We met up again later that summer when CSN came to 
Winnipeg and once again he was extremely open and accessible.

A funny (well, maybe not so funny) aside to my Sioux Falls interview with David was that I had been having the odd gall bladder attack in recent months and had arranged with my doctor to have my gall bladder removed in May. But just prior to my interview with David I felt an attack coming on (anxiety can also affect it and I was anxious over interviewing David) but I gamely went ahead with the interview. Despite a redder than usual face I don't think David had any inkling I was in any discomfort. It was a mild one but, nonetheless, I wasn't going to pass up what could potentially (I didn't know about the CSN Winnipeg date at the time, it had not been announced) be my only interview with David Crosby.

I don't usually do the "fan" thing when conducting interviews because it crosses the line between professional journalism and fandom. But I did bring along my copy of David's autobiography and following the conclusion of our interview I asked him to sign it. $\mathrm{He}$ graciously did so.

What I found was that everyone I contacted was open to discussing Gene. There were few roadblocks. I was fortunate to get access to his closest brothers and sisters as well as his two sons, ex-wife and close personal friends, besides the usual music associates. That added a whole new dimension to Gene's story.

I would love to have interviewed Bob Dylan to glean his thoughts on the impact the Byrds, and in particular Gene, had on his career but Bob doesn't do interviews. David Geffen might have been interesting but I doubt he would take the time to discuss Gene given their relationship.

I would have liked more from Leon Russell but he was recovering and not in the best of health so I took what I could get. Other than that everyone was great.

inkwell.vue 243: John Einarson, "Mr Tambourine Man"

\#47 of 47: John Einarson (johneinarson) Tue 26 Apr 2005 (06:29 AM)

Back to your previous point, Steve, about Gene Clark and Brian Jones, the two do, indeed, have some common threads in terms of their careers. Both were among the first to ever leave a top echelon band while that band was still at the top (Gene probably being the first to do so), both were founding members and integral driving forces in their respective groups getting off the ground yet pushed aside as success came, and both left because of power struggles within their groups that left them out on the side. And both died tragically due to excesses. 